\title{
Probiotik Menurunkan Ekspresi TLR2 dan Aktivasi NF-Kb p50 pada Sel Mononuklear Darah Mencit yang Terpajan Lipopolisakarida E.Coli
}

\section{Probiotics Decrease Expression of TLR2 and Nf-kB p50 Activation in Peripheral Blood Mononuclear Cells of Mice Exposed to E. Coli Lipopolysaccharidae}

\author{
Ni Luh Putu HM${ }^{1}$, Sumakto², Sanarto Santoso ${ }^{3}$ \\ 1,2 Laboratorium IImu Kesehatan Anak Rumah Sakit Umum Dr. Saiful Anwar Malang \\ ${ }^{3}$ Laboratorium Mikrobiologi Fakultas Kedokteran Universitas Brawijaya Malang
}

\begin{abstract}
ABSTRAK
Beberapa tahun terakhir banyak penelitian dilakukan untuk melihat penggunaan probiotik untuk pencegahan maupun untuk pengobatan. Salah satu penggunaan probiotik adalah dalam pengobatan diare. Penggunaan probiotik tersebut berdasarkan respon imun yang dapat ditimbulkan oleh probiotik baik di dalam mukosa usus maupun di sel-sel mononukklear. Penelitian ini bertujuan untuk mengetahui pengaruh probiotik terhadap aktivasi Toll-like receptor (TLR2), TLR4, Nuclear Factor Kappa B p50 dan p65 pada sel mononuklear darah yang terpajan dengan LPS E.coli. Mencit Balb/c dibagi dalam 4 kelompok perlakuan. Satu kelompok mendapat LPS pada hari pertama dilanjutkan dengan probiotik selama 7 hari, satu kelompok LPS saja, satu kelompok probiotik selama 7 hari dan kelompok kontrol tanpa perlakuan. Dilakukan pemeriksaan imunositokimia pada sel mononuklear yang mengekspresikan TLR2, TLR4, dan aktivasi p50 NF-kB dan p65 NF-kB. Hasil penelitian menunjukkankelompok LPS dan probiotik peningkatan ekspresi TLR2 dan TLR4, serta aktivasi NF-kB p50 dan p65, sedangkan pemberian pemberian probiotik mampu menurunkan ekspresi TLR2 dan aktivasi NF-kB p50 $(p<0,05)$ yang disebabkan oleh LPS. Probiotik pada keadaan pajanan dengan LPS E.coli lebih mempengaruhi penurunan ekspresi TLR2 dan menurunkan aktivasi NFkB p50, yang diharapkan mampu menurunkan reaksi inflamasi karena pemberian LPS.
\end{abstract}

Kata Kunci: LPS, NF-kB, probiotik, sel mononuclear, TLR

\begin{abstract}
In recent years much research has been done to investigate use of probiotics for the prevention or treatment. One use of probiotics is for the treatment of diarrhea, where its use is based on an immune response that can be caused by either probiotics in the intestinal mucosa or in mononuclear cells. This study aims to discover the effects of probiotics on the activation of the Toll-like (TLR2), TLR4 receptors, Nuclear Factor Kappa B P50 and p65 in blood mononuclear cells exposed to E. coli LPS. Using mice Balb/c as research subjects, a total of 32 mice were divided into 4 treatment groups. First group received LPS on the first day which continued with probiotics for 7 days, second group received LPS alone on the first day, third group received probiotics for 7 days without treatment and control groups with no LPS and probiotics. After observation for 9 days, examination imunositokimia on mononuclear cells to see the cells that express TLR2, TLR4, and experience the activation of NF-kB P50 and $p 65$ NF-kB. This study shows that the probiotics and LPS groups increased the expressions of TLR2 and TLR4, as well as the activation of NF-kB P50 and $p 65$. While the administration of probiotics reduced the expression of TLR2 and activation of NF-kB P50 $(p<0.05)$ caused by LPS. Giving probiotics after exposure to E. coli LPS significantly decreased TLR2 expression and activation of NFKB P50, due to administration of LPS.
\end{abstract}

Keywords: LPS, NF-kB, probiotic, mononuclear cell, TLR

Jurnal Kedokteran Brawijaya, Vol. 26 No. 3 Februari 2011 Korespondensi: Ni Luh Putu HM. Laboratorium Ilmu Kesehatan Anak Rumah Sakit Umum Dr. Saiful Anwar Malang, Jl. Jaksa Agung Suprapto N. 2 Malang Tel. (0341)366242 Email: ika_fkub@yahoo.com 


\section{PENDAHULUAN}

Sampai saat ini, diare masih merupakan masalah di Indonesia, dan hampir selalu termasuk dalam kelompok 3 penyebab utama kunjungan ke Puskesmas. Angka kesakitannya adalah sekitar 200-400 kejadian diare di antara 1000 penduduk setiap tahunnya (1-3). Sebagai suatu infeksi, diare terbanyak disebabkan oleh bakteri, $E$ Coli (1-4).Terjadinya diare sangat berkaitan dengan peranan sistem imun terutama sistem imun mukosa usus, karena sebagain besar masuknya antigen penyebab diare melalui sistem pencernaan.

Keunikan sistem imun mukosa usus dibandingkan dengan sistem imun sistemik terletak pada pajanan yang terjadi terus-menerus dengan antigen, baik yang berasal dari makanan ataupun dari lingkungan yang disertai pula dengan keberadaan mikrobiota dalam saluran cerna yang berjumlah $>10^{14}(5)$. Dengan adanya peranan mikrobiota usus yang sangat penting dalam sistem kekebalan tubuh, maka mulai dikembangkan penambahan mikrobiota ke dalam makanan terutama golongan bakteri asam laktat yang akan mempengaruhi sistem kekebalan tubuh. Dalam beberapa dekade terakhir telah berkembang pesat penelitian-penelitian yang dilakukan untuk melihat peranan mikrobiota dalam sistem kekebalan (6-8).

Probiotik adalah mikrobiota yang mampu merangsang sistem kekebalan tubuh dengan berbagai mekanisme, baik sistem kekebalan tubuh innate maupun adaptif dengan berbagai mekanisme, serta dapat mempengaruhi mikrobiota yang lain. Peran probiotik sampai saat ini banyak dipergunakan dalam pengobatan tidak hanya dalam bidang saluran pencernaan, namun juga pada penyakit alergi dan dapat dipergunakan sebagai upaya untuk pencegahan (9-12). Probiotik dapat merangsang sistem kekebalan tubuh, baik melalui sistem kekebalan innate maupun adaptif. Probiotik menginduksi respon imun melalui peranan TLR dan Nuclear Factor-Kappa B (NF-kB) yang merupakan faktor transkripsi yang berperan penting dalam merangsang dan mengkoordinasi respon imun innate dan adaptif $(2,13)$. Pada penelitian untuk melihat peranan probiotik setelah pajanan dengan LPS, menunjukkan bahwa pemberian probiotik terutama mampu menurunkan ekspresi TLR4 pada Human Embryonic Kidney (HEK) yang mengalami colitis. Namun peranan probiotik di sini juga dapat melibatkan TLR2, karena komponen Lipoteichoic Acids (LTA)(14,15).

Penelitian yang dilakukan untuk melihat respon kekebalan innate karena pemberian probiotik telah banyak dilakukan, baik dengan melihat respon kekebalan innate pada sel mukosa usus maupun di dalam sirkulasi darah. Penelitian juga telah banyak dilakukan untuk melihat efek probiotik sebagai pencegahan maupun sebagai terapi(1620). Namun demikian, belum adanya pembuktian secara langsung pengaruh pemberian probiotik terhadap ekspresi TLR2, TLR4, dan aktivasi NF-B pada sel mononuklear di darah tepi dalam menghadapi pajanan patogen pada mukosa usus, oleh karena itu, dengan menggunakan hewan coba mencit ingin diketahui pengaruh probiotik terhadap TLR2, TLR4, dan NF-B pada pajanan dengan LPS E.coli.

\section{METODE}

\section{Hewan Coba}

Hewan coba digunakan mencit galur Mus musculus
(Balb/c mice), dari kandang hewan percobaan Pusat Veterinaria Farma Jl. Ahmad Yani Surabaya, dengan jenis kelamin jantan. Kriteria inklusi adalah usia mencit 10-12 minggu, berat badan 30-40 g, dengan kondisi mencit sehat dan bebas penyakit. Hewan coba dieksklusi jika sakit dalam pengamatan, yang tampak dari perubahan perilaku hewan (perubahan pola makan/minum dan aktivitas) dan tanda-tanda klinis penting lainnya (penurunan berat badan, pola nafas, diare, muntah, dan sebagainya), atau mati dalam pengamatan.

\section{Probiotik}

Probiotik yang dipakai per-kemasannya (sachet) didapatkan jumlah bakteri hidup (total viable count) dari jenis Mix bacteria dengan komposisi Lactobacillus rhamnosus R0011 1,9×109 cfu, dan Lactobacillus acidophilus R0052 0,1×109 cfu. Probiotik diberikan dengan dosis $10^{\circ} / \mathrm{kgBB} /$ hari sehingga setiap mencit akan mendapatkan dosis rata-rata 3x107 CFU. Probiotik ini akan dilarutkan dalam media D5\% sebanyak 0,5 cc dan diberikan melalui sonde lambung setiap hari (sekali sehari) selama 7 hari untuk kelompok Probiotik-LPS dan kelompok Probiotik.

\section{LPS}

LPS yang dipakai adalah LPS produk Sigma dengan kode produk L2880 berasal dari dari bakteri Escherichia coli serotype 055:B5, dengan dosis $250 \mu \mathrm{g} / \mathrm{kg} \mathrm{BB}$, sehingga setiap mencit akan mendapatkan dosis rata-rata 7,5 $\mathrm{gg}$. LPS ini akan diencerkan dengan larutan $\mathrm{NaCL} 0,9 \%$ dengan perbandingan 100:1, dan diberikan melalui sonde lambung, sekali pada hari pertama penelitian untuk kelompok Probiotik-LPS dan kelompok LPS.

\section{Desain Penelitian}

Penelitian ini merupakan penelitian eksperimental (true experimental) dengan desain studi randomized control group, yang dilakukan di laboratorium farmakologi dan biomedik Fakultas Kedokteran Universitas Brawijaya Malang selama 1 bulan, yaitu bulan Februari 2010. Besar sampel penelitian ditentukan dengan menggunakan rumus Federer, dengan menggunakan 4 kelompok penelitian, sampel penelitian yang dibutuhkan adalah $\geq 6$ sampel per kelompok, dengan tambahan 2 sampel untuk menghindari subjek yang tereksklusi sehingga total sebanyak 32 sampel penelitian diperoleh dengan 8 sampel per kelompok. Tiga puluh dua ekor mencit jantan, yang telah memenuhi kualifikasi sebagai subek penelitian, dilakukan adaptasi di lingkungan baru (di kandang di laboratorium farmakologi FKUB) selama 7 (tujuh) hari. Perawatan rutin meliputi pemberian makanan yang dilakukan setiap hari, penggantian air minum juga dilakukan setiap hari, sedangkan pembersihan kandang dan penggantian sekam (sebagai alas kandang) dilakukan seminggu sekali untuk menjaga kebersihan dan kenyamanan subjek penelitian

Setelah dilakukan persiapan, ke-32 ekor mencit ini secara random dibagi menjadi empat kelompok, dimana masingmasing kelompok berisikan 8 (delapan) ekor mencit. Pemberian probiotik (untuk kelompok Probiotik-LPS dan kelompok Probiotik) melalui sonde lambung dilakukan dengan bantuan tenaga berpengalaman. Pemberian LPS pada pertama (untuk kelompok Probiotik-LPS dan 
kelompok LPS) dilakukan dengan cara yang sama dengan pemberian probiotik. Pencatatan harian dilakukan dengan melihat perilaku subjek penelitian, apakah terlihat sakit, tidak aktif bergerak, didapatkan luka-luka, dan juga dilakukan pemeriksaan kotoran hewan coba. Setiap 3 (tiga) hari dilakukan penimbangan berat badan ulang dari subyek penelitian. Pada hari ke-9 dilakukan euthanasia pada seluruh mencit dari tiap kelompok dengan menggunakan eter. Setelah hewan coba dipastikan telah mati, dilakukan pengambilan darah melalui intrakardiak.

\section{Teknik Pemeriksaan Imunohistokimia}

Darah tepi yang dipergunakan tidak boleh lebih dari 8 jam, dengan diberikan antikoagulan, kemudian ditambah PBS (Phosphate buffer saline) dengan perbandingan 1:1 (200 $\mu \mathrm{L}$ darah), dan ditambahkan LSM (Lymphocyte Separation Medium). Setelah dilakukan sentrifugasi selama 30 menit dengan kecepatan 1000 rpm akan terbentuk 4 lapisan yaitu: plasma, cincin bufficoat, ficol dan eritrosit. Diambil lapisan cincin bufficoat dan ditambahkan dengan PBS 3-5x volume bufficoat.

Dilakukan sentrifugasi selama 10 menit dengan kecepatan 1000 rpm, bisa dilakukan 2-3 kali sampai terbentuk sedimen atau endapan yang diambil dan diteteskan di gelas objek 2 tetes dan dilakukan pembuatan hapusan. Hapusan yang sudah kering, dicuci dengan PBS dengan $\mathrm{pH}$ 7,4 selama 5 menit, dan diinkubasi dengan $\mathrm{H}_{2} \mathrm{O}_{2} 3 \%$ selama 20 menit, kemudian dicuci kembali dengan PBS selama 5 menit sebanyak 3 kali. Dilakukan blocking unspesific protein, dan inkubasi dalam FBS 5\%, dilanjutkan dengan inkubasi menggunakan antibodi primer (monoclonal NFkBp65/50 - TLR2/4) selama satu malam dalam suhu $4^{\circ} \mathrm{C}$, kemudian dicuci dengan PBS pH 7,4 selama 5 menit sebanyak 3 kali. Setelah itu, dilakukan inkubasi dengan antibodi sekunder selama 60 menit, dan dicuci dengan PBS, dan diinkubasi kembali dalam enzim SA-HRP selama 40 menit dan dicuci dengan PBS. Sediaan yang terjadi diberikan dengan kromogen DAB (Diamono Benzidine) selama 20 menit dan dicuci dengan PBS, kemudian dibilas dengan deionize water atau aquades steril selama 5 menit sebanyak 3 kali. Dilakukan pewarnaan counterstain dengan Mayer Haematoxilen selama 10 menit, dan dicuci dengan aquades selama 5 menit sebanyak 3 kali, dan dikeringkan. Dilakukan pengamatan di bawah mikroskop, dengan menghitung jumlah sel rata-rata yang mengekspresikan atau mengalami aktivasi dalam 5 lapangan pandang.

\section{Analisis Statistik}

Analisis deskriptif dilakukan untuk mendiskripsikan gambaran hasil pengamatan berupa profil sel yang mengekspresikan TLR-2, TLR-4, aktivasi NF-kB p50 dan NFkB p65 untuk masing-masing kelompok. Analysis of Variance (ANOVA) dilakukan untuk menganalisa pengaruh pemberian probiotik pada tikus dengan pemberian LPS terhadap ekspresi TLR-2, TLR-4, dan aktivasi NF-kB p50 dan $\mathrm{p}$ 65. Dilakukan analisis jalur untuk melihat kemungkinan jalur yang dipergunakan pada pajanan dengan LPS dan pemberian probiotik. Data dianalisis dengan menggunakan tingkat kepercayaan $95 \%(\alpha=0,05)$, dengan menggunakan program SPSS versi 17.

\section{HASIL}

Karakteristik gambaran ekspresi TLR dan aktivasi NF-kB p 50 disajikan pada Gambar 1.
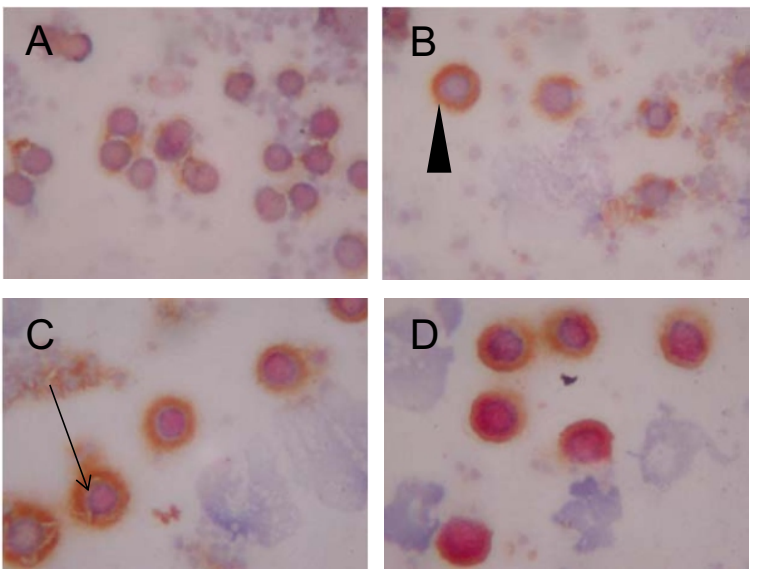

Gambar 1: Sel yang mengespresikan TLR dan aktivasi NF-kB

\section{Keterangan:}

Sel yang mengekspresikan NFkBp50 menunjukkan inti sel yang berwarna merah (panah hitam) dan sel yang mengpresikan TLR akan menunjukkan membran sel yang berwarna coklat (kepala panah hitam). (A. kelompok kontrol. B. Kelompok probiotik, C. kelompok LPS dan D. Kelompok LPS dan probiotik)

Ekspresi TLR-2 dan TLR4 serta Aktivasi NF-kB p50 dan p65 pada Masing-masing Kelompok

Data ekspresi TLR-2, TLR 4 dan aktivasi NF-kB p50 dan p65 disajikan dalam nilai rata-rata (mean) pada masing-masing kelompok (Tabel 1).

Analisis yang dilakukan pada ekspresi TLR-2 di masingmasing kelompok menunjukkan rata-rata tertinggi pada kelompok yang mendapat LPS $(20,88 \pm 1,093)$ dibandingkan kelompok yang lain, dan terdapat penurunan setelah pemberian probiotik, pada kelompok LPS+probiotik $(12 \pm 1,363)$. Dari analisis dengan pos hoc menunjukan perbedaan bermakna untuk masing-masing kelompok, dengan nilai $\mathrm{p}<0,05$.

Analisa yang dilakukan pada ekspresi TLR-4 menunjukkan rata-rata tertinggi pada kelompok yang mendapat LPS dan probiotik $(18,88 \pm 0,833)$ dibandingkan kelompok yang lain. Sedangkan hasil analisis post hoc menunjukan tidak ada perbedaan bermakna untuk kelompok yang mendapat LPS dengan probiotik $(p=0,112)$ dan antara kelompok probiotik dan LPS+probiotik $(p=0,428)$.

Pada kelompok yang mendapat probiotik terdapat peningkatan ekspresi TLR4 yang lebih tinggi dibandingkan dengan kelompok LPS, yang secara statistik tidak terdapat perbedaan bermakna diantara kedua kelompok. Hal ini menunjukan bahwa probiotik lebih menimbulkan peningkatan ekspresi TLR4 dibandingkan LPS. Pajanan dengan LPS diduga lebih mempergunakan TLR2 untuk menimbulkan respon imunologis, sedangkan probiotik lebih mempergunakan TLR4.

Peningkatan aktivasi NF-kB p65 yang terjadi pada kelompok probiotik berhubungan dengan peningkatan respon imunologis atau kesigapan sistem imunologis dalam menghadapi pajanan patogen, karena 
berhubungan dengan respon imunologis, reaksi antiapoptosis, dan proliferasi sel-sel imunologi.

Berbeda dengan aktivasi p50, di mana tertinggi didapatkan pada kelompok yang mendapat probiotik, menunjukkan bahwa pajanan LPS lebih menimbulkan peningkatan aktivasi p50. Hal ini berhubungan dengan peranan p50 sebagai suatu faktor transkripsi pro inflamasi.

Tabel 1. Nilai rata-rata ekspresi TLR2, TLR4 dan aktivasi NF-kB p50 p65

\begin{tabular}{lllll}
\hline Kelompok & TLR2 & TLR4 & P50-NFKb & P65-NFKb \\
& & & & \\
\hline Kontrol & $2,38 \pm 0,532$ & $2,75 \pm 0,590$ & $3,63 \pm 0,680$ & $3,13 \pm 0,693$ \\
LPS & $20,88 \pm 1,093$ & $14,13 \pm 1,575$ & $19,5 \pm 1,363$ & $11,50 \pm 1,150$ \\
Probiotik & $6,38 \pm 0,706$ & $15,88 \pm 1,445$ & $8,38 \pm 0,730$ & $16,88 \pm 1,260$ \\
Probiotik+LPS & $12 \pm 1,363$ & $18,88 \pm 0,833$ & $10 \pm 1,150$ & $18,13 \pm 1,156$ \\
\hline
\end{tabular}

Analisa Jalur dari Respons Imun Pemberian Probiotik, LPS, dan Keduanya

Analisa jalur dilakukan pada setiap kelompok perlakuan untuk mendapatkan pola respons imun yang terjadi karena pemberian probiotik, dan LPS, dengan menggunakan uji korelasi Sperman. Uji korelasi tersebut bertujuan mencari hubungan yang paling bermakna, selain itu untu melihat analisis jalur yang kemungkinan terjadi pada penelitian dengan menggunakan path analysis. Pada kelompok probiotik yang digambarkan pada gambar 2 didapatkan bahwa probiotik memberikan pengaruh secara bermakna pada kedua ekspresi TLR2 dan TLR4 ( $p: 0,000)$, namun hubungan antara pemberian probiotik lebih besar melalui ekspresi TLR4 ( $r=0,87$; $r=0,792)$. Sedangkan untuk aktivasi p65 NF-kB lebih dipengaruhi oleh aktivasi TLR4 dibandingkan melalui TLR2 $(p=0,000 ; r=0,800$ dan $p=0,003 ; r=0,688)$.

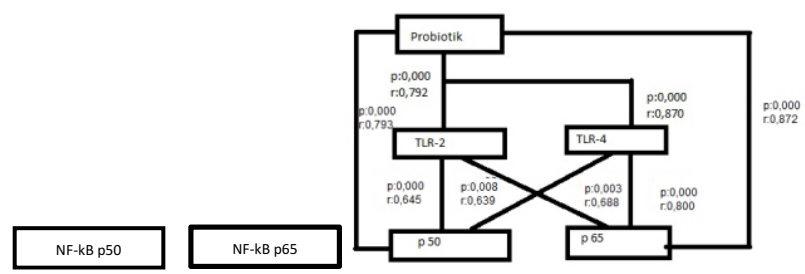

Gambar 2. Pengaruh pemberian probiotik dibandingkan dengan kontrol

Hasil analisis jalur menunjukkan, bahwa pemberian probiotik menimbulkan peningkatan aktivasi NF-kB, terutama p65 dibandingkan dengan NF-kB p50 (p>0,05). Koefisien pengaruh probiotik secara langsung terhadap aktivasi NF-kB p65 sebesar 1,269 sedangkan kalau melalui TLR2 sebesar 1,462. Dalam meningkatkan aktivasi NF-kB p65, ternyata tidak melaui TLR2 karena secara statistik peningkatan ekspresi TLR2 tidak memberikan kontribusi yang bermakna terhadap peningkatan aktivasi NF-kB p65 ( $p>0,05)$.

Hasil yang berbeda didapatkan pada kelompok LPS, yang menunjukkan terdapat hubungan yang bermakna antara pemberian LPS dengan ekspresi TLR 2 dan TLR 4, di mana hubungan lebih besar melalui TLR2 ( $p=0,000 ; r=0,875$ dan $p=0,000 ; r=0,871$ ). Aktivasi NF-kB $p 50$ lebih dipengaruhi oleh ekspresi TLR4 dibandingkan dengan TLR $2(p=0,000$; $r=0,816$ dan $p=0,000 ; r=0,930)$. Terdapat hubunganyang bermakna antara pemberian LPS dengan aktivasi NF-kB $p 50$ secara langsung $(p=0,000, r=0,872)$.

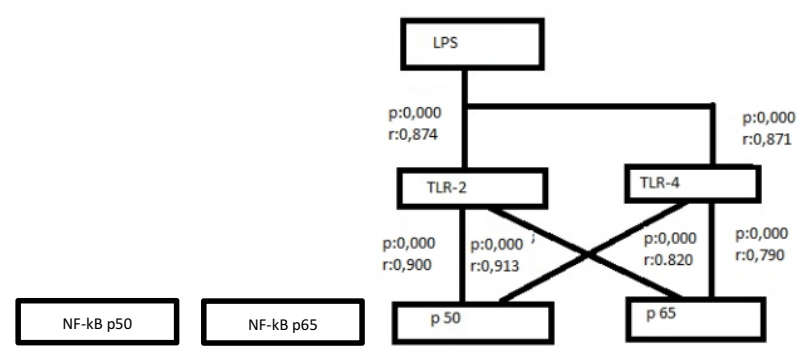

Gambar 3. Pengaruh pemberian LPS dibandingkan dengan kelompok kontrol.

Analisis jalur yang dilakukan pada kelompok dengan pajanan LPS menunjukkan bahwa pajanan dengan LPS akan meningkatkan aktivasi NF-kB p50 secara langsung dengan koefisien 0,918 . Jalur yang dipergunakan lebih melalui TLR4 dibandingkan melalui TLR2 (koefisien 1,454 dibandingkan 1,275).

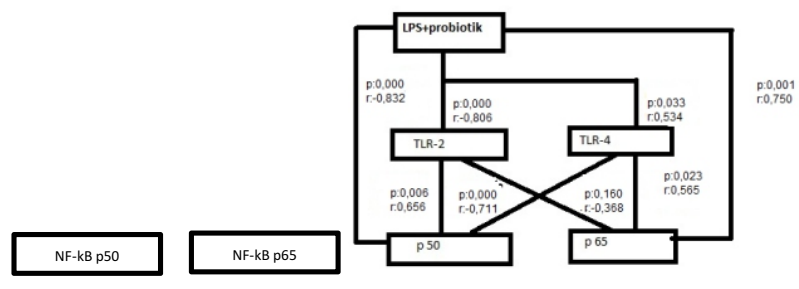

Gambar 4. Pengaruh pemberian Probiotik setelah pajanan dengan LPS

Pada kelompok probiotik yang dipajan dengan LPS respon imun dipengaruhi melalui jalur TLR-2( $p=0,000 ; r=-0,806)$, dibandingkan melalui TLR $4(p=0,033, r=0,534)$. Aktivasi NF-kB p65 mempunyai hubungan yang paling besar dengan pemberian probiotik, dibandingkan dengan aktivasi TLR maupun TLR 4 ( $p=0,000, r=0,750$ ) (Gambar 4). Analisis jalur yang dilakukan menunjukkan pemberian probiotik setelah pajanan dengan LPS secara langsung akan menurunkan aktivasi NF-kB p50 secara langsung dengan koefisien 1,182. Penurunan ini lebih melalui jalur penurunan ekspresi TLR2 dibandingkan dengan melalui TLR 4 (koefisien 1,59 dibandingkan 1,288).

\section{DISKUSI}

Probiotik pada penelitian ini diberikan selama 7 hari, sama dengan hasil penelitian yang dilakukan oleh Galdeano (2006), yang membuktikan bahwa pemberian L.casei $10^{8}$ UFC pada mencit memberikan ekspresi TLR2 meningkat secara bermakna dibandingkan kelompok kontrol pada pemberian hari ke 5 dan ke 7, sedangkan pada pemberian 
hai ke-2 belum memberikan perbedaan bermakna. Sedangkan peningkatan IL6 dan IgA berbeda bermakna setelah pemberian hari ke-7 (21). Selain itu, Galdeano (2007) melaporkan bahwa pemberian probiotik (L.helveticus) memberikan peningkatan bermakna setelah pemberian selama 7 hari (22). Dalam laporannya, Galdeano (2007) juga membandingkan respon imun yang terjadi pada pemberian probiotik dengan dosis berbeda, ternyata probiotik akan memberikan efek baik pada mukosa maupun secara sistemik dengan dosis $10^{8}-10^{9}$ CFU/hari(22,23).

Dosis LPS E.coli yang dipergunakan adalah $250 \mu \mathrm{g} / \mathrm{kgBB}$, sesuai dengan penelitian yang dilakukan oleh Purswani et al (2002) didapatkan bahwa LD $_{50}$ LPS adalah 500-1000 $\mu \mathrm{g}$ dan dengan dosis $200 \mu \mathrm{g}$ akan memberikan respon imun tanpa meningkatkan kematian. Pemberian dosis LPS kurang dari $20 \mu \mathrm{g}$ tidak memberikan respon imun pada mencit sehat (24). Penelitian lain juga menyebutkan bahwa dosis LPS yang aman untuk binatang coba adalah berkisar antara 0,25-2,5 $\mu / \mathrm{g} \mathrm{BB}(3,25)$.

Ekspresi TLR 2, TLR4 dan Aktivasi NF-kB p50 dan p65 pada Kelompok Kontrol

Kelompok kontrol menunjukkan ekspresi TLR2, TLR4 dan aktivasi NF-kB pada mencit yang sehat, sebelum terpapar LPS. Hal ini menunjukkan bahwa secara konstitutif variabel respon imun yang diteliti telah diproduksi sebelum dilakukan intervensi pajanan LPS dan probiotik. Belum ada data yang memberikan nilai absolut ekspresi TLR2, TLR4 dan aktivasi NF-kB p50 dan p65 pada mencit yang normal. Penelitian terdahulu memberikan hasil yang bervariasi untuk nilai tersebut baik di lamina propia maupun di sel mononuklear. Penelitian yang dilakukan oleh Galdeano (2006) pada lamina propia mencit Balb/c usia 6-8 minggu dengan berat badan $25-30 \mathrm{mg}$ yang memeriksa tingkat respons imun TLR-2 pada lamina propria dan Peyer patch pada usus halus secara in vivo. Penelitian ini menggunakan pemeriksaan imunofluoresein dengan poliklonal antibodi spesifik pada mencit untuk TLR-2, memberikan hasil ekspresi tingkat respons imun TLR2 yang positif baik pada lamina propria juga pada Peyer patches pada kelompok kontrol, sebelum diberikan paparan dengan L.casei. Kelompok kontrol mengekspresikan TLR2 secara lemah, dan berbeda secara bermakna bila dibandingkan dengan kelompok perlakuan (21).

Miettinen et al (2008) meneliti ekspresi TLR2 dan TLR4 pada makrofag donor, menunjukkan ekspresi lemah pada sel makrofag sebelum dilakukan perlakuan berupa pajanan dengan Lactobacillus rhamnosus dan Streptococcus pyogenes (26). Hasil yang sama juga pada penelitian oleh Ishida-Fujii (2007) menunjukkan bahwa sebelum pajanan dengan LPS dari E.coli maupun dengan Lactobacillus casei 15, telah ada aktivasi NF-kB p50 dan p65 pada kelompok kontrol(17).

Ekspresi TLR2, TLR4 dan Aktivasi NF-kB P50 dan P65 oleh karena Pajanan LPS

Pajanan dengan LPS lebih menimbulkan peningkatan ekspresi TLR2 dibandingkan dengan TLR4 ( $p=0,000)$. Sedangkan dari analisis hubungan pajanan LPS menunjukkan bahwa pajanan LPS E.coli mempunyai hubungan yang bermakna baik dengan jalur TLR2 maupun TLR4, tetapi menunjukkan korelasi yang lebih besar dengan TLR2 ( $p=0,000 ; r=0,875)$ dibandingkan dengan
TLR4 ( $p=0,000 ; r=0,871)$. Penelitian yang terdahulu menyebutkan bahwa pajanan LPS menimbulkan respon imun melalui aktivasi atau ikatan dengan TLR4. Hal ini terutama disebabkan oleh bagian LPS yaitu lipid $A$ $(3,27,28)$. Penelitian oleh Bhattacharyya et al (2008) dengan menggunakan mencit yang mengalami delesi gen TLR4, menunjukkan peningkatan produksi ROS (Reactive Oxygen Species), peningkatan sekresi IL-8, aktivasi NF-kB dengan meningkatkan fosforilasi IK-kB (29). Hasil yang sama dilakukan oleh Covert et al (2005) menunjukkan LPS mampu mengaktivasi NF-kB terutama melalui jalur MyD88-dependent dibandingkan melalui jalur MyDD88independent (4).

Penelitian ini menunjukkan bahwa pemberian LPS berhubungan baik dengan TLR2 maupun TLR4. Hasil ini sama dengan beberapa penelitian yaitu pada mencit dengan memberikan LPS secara intraperitoneal dan dilakukan pemeriksaan pada sel makrofag, menunjukan peningkatan ekspresi TLR2 dibandingkan TLR4 $(4,24)$

Pajanan dengan LPS menunjukkan aktivasi lebih tinggi pada NF-kB p50 dibandingkan p65 $(p=0,000)$, kedua aktivasi tersebut berbeda secara bermakna dibandingkan dengan kelompok kontrol. Hasil ini mendukung hasil penelitian sebelumnya bahwa LPS akan menimbulkan respon imun dengan peningkatan aktivasi sebagai faktor transkripsi yang akan menimbulkan reaksi pro inflamasi. Ishida-Fujii et al (2007) melaporkan aktivasi NF-kB baik p50 maupun p65 pada sel makrofag mencit yang mendapat pajanan dengan E.coli. Hal ini didukung juga dengan penelitian oleh Gadjeva et al (2004) melakukan penelitian pada mencit yang mengalami delesi pada gen yang mengkode NF-kB p50 dan p65. Pada penelitian itu menghasilkan bahwa mencit tersebut akan mengalami syok yang disebabkan oleh LPS (30).

Hasil analisis jalur menunjukkan bahwa peningkatan aktivasi NF-kB p50 lebih melalui jalur peningkatan ekspresi TLR 2 dibandingkan dengan TLR4. Selain itu pada analisis korelasi menunjukkan bahwa peningkatan aktivasi NF-kB p50 mempunyai hubungan dengan pemberian LPS sendiri $(p=0,000, r=0,872)$. Temuan ini menunjukkan bahwa pajanan LPS tidak hanya mempengaruhi TLR secara langsung, namun juga pada faktor transkripsi NF-kB untuk memulai proses inflamasi.

Karrasch (2008) menyatakan bahwa terdapat beberapa jalur aktivasi NF-kB dalam sel imunokompeten pejamu. Jalur klasik/cannonical diaktifkan melalui Toll-Like Receptor dan kemudian akan diikuti oleh aktivasi dari NFkB melalui jalur heterodimer p65/p50 serta p105 pada makrofag, yang kemudian setelah proses fosforilasi, ubikuitinisasi dan degranulasi IkB kompleks kemudian mengalami translokasi ke nukleus untuk memulai suatu proses transkripsi. Jalur yang lain disebut jalur alternatif/non-cannonical tidak melibatkan TLRs tetapi secara langsung pada NF-kB p100 pada sel limfosit B dan T $(31,32)$. Seperti halnya Dharma (2009), dengan penurunan ekspresi NF-kB p105 yang signifikan tanpa melalui peningkatan ekspresi TLR, menunjukkan bahwa selain melalui jalur klasik, yaitu TLR-2 dan TLR-4, LPS juga dapat mempengaruhi NF-kB p105 melalui jalur non-TLR atau jalur alternatif, sehingga dapat terjadi aktivasi NF-kB p50 homodimer di nukleus(33).

Ekspresi TLR2, TLR4 dan Aktivasi NF-kB p50 dan p65 


\section{dengan Pemberian Probiotik}

Pemberian probiotik selama 7 hari menghasilkan peningkatan bermakna ekspresi TLR2dan TLR4bila dibandingkan kelompok kontrol. Namun apabila dibandingkan dengan kelompok LPS, hanya ekspresi TLR2 yang berbeda bermakna. Hal ini didukung dari hasil analisis jalur yang menunjukkan pemberian probiotik akan meningkatkan aktivasi NF-kB p65 lebih melalui ekspresi TLR4 dibandingkan TLR2. Hasil yang sama dilaporkan oleh Galdeano et al (2006) bahwa pemberian probiotik dari Lactobacillus casei secara oral meningkatkan ekspresi TLR2 pada mononuklear sel di mukosa saluran pencernaan dibandingkan kelompok kontrol. Peningkatan ini paling bermakna setelah pemberian probiotik selama 7 hari (21).

Peranan probiotik dalam memodulasi respon imun sangat bervariasi, tergantung pada strain yang dipergunakan, demikian juga pengaruh pada NF-kB p50 dan p65 sebagai faktor transkripsi. Penelitian ini menunjukkan peningkatan aktivasi NF-kB p50 $(8,380 \pm 0,730)$ dan p65 $(16,880 \pm 1,260)$, yang berbeda secara bermakna dengan kelompok kontrol ( $p=0,003$ untuk $p 50$ dan $p=0,000$ untuk p65) dan dibandingkan kelompok dengan pemberian LPS $(p=0,000$ untuk p50 dan $p=0,020$ untuk p65). Petrof et al (2004) melaporkan pretreatment sel colon mencit dengan probiotik yang terdiri dengan Sterptococcus salivarius, $L$ casei, L. plantarum, L acidophilus, L. delbrueckii, Bifidobacterium longum dan $B$ infantis akan meningkatkan ekspresi NF-kB, namun akan menurunkan ekspresi NF-kB setelah pemberian dengan TNF- $\alpha$ dibandingkan hanya dengan pemberian TNF- $\alpha$. Hal ini tentu akan menurunkan reaksi inflamasi karena TNF- $\alpha$ (34). Penelitian yang dilakukan oleh Miettinen et al (2008) menghasilkan bahwa baik Lactobacillus rhamnosus dan Streptococcus pyogenes akan meningkatkan aktivasi NF$\mathrm{kB}$, meskipun dengan melalui regulasi gen yang berbeda, di mana respon imun oleh karena probiotik lebih berhubungan dengan TLR2. Hal ini diduga berkaitan dengan kemampuan makrofag untuk membedakan mikroba patogen dan komensal $(17,26)$. Sedangkan penelitian pada tahun 2000 menunjukkan bahwa pemberian probiotik dan streptococcus mampu meningkatkan aktivasi NF-kB, namun pada pemberian streptococcus tidak diikuti dengan peningkatan sekresi IFN- $\alpha$, yang diduga disebabkan sifat patogen dari Streptococcus (35)

Respon imun yang disebabkan oleh probiotik sangat tergantung pada strain yang dipergunakan. Pada tahun 2005, Ruiz et al menunjukan hasil bahwa B.lactis akan meningkatkan fosforilasi NF-kB p65 yang selanjutkan akan meningkatkan sekresi IL-6, namun B.vulgatus tidak meningkatkan sekresi IL-6. Meskipun terdapat peningkatan aktivasi NF-kB p65 sebagai salah satu respon pro-inflamasi, namun pada pemeriksaan secara histologi jaringan tidak menunjukkan adanya tanda-tanda inflamasi. Hal ini diduga adanya mekanisme umpan balik dari host untuk mengontrol respon imun yang terjadi (36). Hasil yang berbeda dilaporkan oleh Lin et al (2009), dimana pemberian probiotik tidak mempengaruhi aktivasi NF-kB (16).

\section{Pengaruh Pemberian Probiotik terhadap Pajanan LPS.}

Pemberian probiotik pada mencit yang sebelumnya telah terpajan dengan LPS E.coli merupakan suatu model penggunaan probiotik sebagai salah satu pengobatan pada infeksi yang disebabkan oleh bakteri gram negatif. Pada kelompok LPS + probiotik, menunjukkan peningkatan ekspresi TLR2, TLR4dan aktivasi NF-kB p50 dan p65. Peningkatan ekspresi TLR2 dan TLR4 berbeda bermakna bila dibandingkan dengan kelompok controldan apabila dibandingkan dengan kelompok LPS, terdapat penurunan ekspresi TLR 2 namun terdapat peningkatan ekspresi TLR 4.

Analisis jalur yang dilakukan menunjukkan bahwa pemberian probiotik pada pajanan dengan LPS akan menurunkan aktivasi NF-kB p50 melalui penurunan ekspresi TLR2, dibandingkan pengaruh probiotik melalui TLR4. Hasil ini menunjukkan bahwa pemberian probiotik pada keadaan pajanan dengan LPS akan menurunkan ekspresi TLR2 yang diakibatkan reaksi terhadap LPS, meskipun penurunan tersebut tidak menyamai keadaan tanpa pajanan dengan LPS (kontrol) atau pemberian probiotik saja. Hasil yang berbeda di mana pada pemberian probiotik setelah paparan dengan LPS menimbulkan peningkatan ekspresi TLR4. Hal ini diduga karena pada keadaan pajanan dengan LPS, probiotik lebih menggunakan jalur TLR4 karena pada pemberian LPS sudah menggunakan jalur TLR2. Hal ini dimungkinkan karena komponen dari probiotik sendiri dalam hal ini L.rhamnosus dan L.acidophilus mempunyai komponen LTA yang akan dikenali oleh TLR2 (15).

Hasil ini berbeda dengan penelitian sebelumnya yang belum memberikan hasil pengaruh probiotik pada pajanan dengan LPS terhadap ekspresi TLR2. Penelitian tersebut lebih banyak menunjukkan pengaruh probiotik tersebut melalui ekspresi TLR4. Hal ini dimungkinkan karena adanya bukti sebelumnya bahwa LPS menimbulkan respon melalui TLR4. Penelitian yang dilakukan oleh Lee et al (2009) menunjukkan bahwa pemberian probiotik menurunkan ekspresi TLR4 pada human embryonic kidney (HEK) yang mengalami colitis karena efek dari 2,4,6trinitrobenzenesulfonic (TNBS) (14)

Aktivasi NF-kB p50 dan p65 pada kelompok LPS+probiotik menunjukan peningkatan yang bermakna apabila dibandingkan kelompok kontrol $(p=0,000)$ dan penurunan yang bermakna pada aktivasi NF-kB p50 bila dibandingkan kelompok pajanan LPS $(p=0,000)$. Hasil yang berbeda di mana pada pemberian probiotik pada pajanan LPS meningkatkan aktivasi NF-kB p65 yang berbeda bermakna apabila dibandingkan dengan kelompok LPS. Namun aktivasi ini tidak berbeda secara bermakna apabila dibandingkan dengan kelompok probiotik. Hal ini menunjukan bahwa pemberian probiotik selama 7 hari pada pajanan LPS atau infeksi oleh bakteri gram negatif, mampu menurunkan aktivasi NF-kB yang disebabkan oleh LPS terutama $\mathrm{p} 50$ mendekati keaadaan dengan pemberian probiotik, namun belum menyamai keadaan kontrol.

Pada tahun 2009, Lee et al menunjukan bahwa pemberian probiotik (Lactobacillus suntoryeus, B.longum, dan L.plantarum), menurunkan aktivasi NF-kB pada human embryonic kidney (HEK) yang mengalami colitis karena efek dari 2,4,6-trinitrobenzenesulfonic (TNBS), di mana respon tersebut tergantung pada strain yang dipergunakan (14). Terdapat beberapa mekanisme yang menjadi dasar penurunan aktivasi NF-kB tersebut, antara lain dengan menghambat translokasi NF-kB ke dalam nucleus $(18,37)$, menghambat fosforilasi Ik-B $(38,39)$, 
menghambat aktivasi gen yang mengkode transaktivasi NF-kB dan degradasi IkB $\alpha(40)$, ataupun melalui hambatan proses degradasi lk-B oleh proteasome (34).

Peningkatan aktivasi NF-kB p65 pada kelompok LPS+probiotik yang berbeda secara bermakna apabila dibandingkan dengan kelompok LPS, perlu dipertimbangkan pengaruh waktu pada penelitian ini.Pemeriksaan respon imun dilakukan pada hari ke delapan setelah pemberian LPS dan 7 hari pemberian probiotik, sehingga sudah terjadi toleransi terhadap LPS. Couper et al (2008) menyebutkan bahwa respon imun maksimal setelah paparan LPS (IL2 dan IFN- $\gamma$ ) terjadi setelah 3 sampai 6 jam setelah paparan, dan kemudian akan menurun(41). Penelitian yang dilakukan oleh Asihing (2010) menunjukkan bahwa pemberian probiotik tidak memberikan pengaruh yang bermakna pada mencit yang terpajan dengan LPS E.coli (42). Selain itu, hal tersebut dapat disebabkan oleh peranan NF-kB yang tidak hanya sebagai respon proinflamasi, namun juga pada anti inflamasi, apoptosis maupun proliferasi sel. Gadjeva, et al (2004) menunjukkan bahwa aktivasi NF-kB p50 dan p65 berfungsi untuk menhambat reaksi inflamasi oleh karena pemberian LPS (30). Meskipun pada beberapa penelitian yang lain menyebutkan bahwa efek proteksi tersebut lebih berhubungan dengan aktivasi NF-kB p50 (4,43-45) Pengaruh LPS juga tergantung pada dosis, di mana pemberian dosis rendah $(100 \mu \mathrm{g} / \mathrm{ml})$ respon inflamasi maksimal akan terjadi pada 12 jam setelah pajanan, sedangkan dosis $1000 \mu \mathrm{g} / \mathrm{ml}$ pada 24 jam dan kemudian akan menurun (46).

Berdasarkan hasil penelitian ini menunjukkan bahwa probiotik dalam hal ini L. rhamnossus dan L.acidophilus mempunyai peranan dalam meningkatkan respon imun, yaitu dengan meningkatkan ekspresi TLR2 dan TLR4 serta aktivasi NF-kB p50 dan p65, dibandingkan dengan kelompok kontrol. Selain itu pemberian probiotik juga bermanfaat pada keadaan sakit, terutama oleh E.coli sebagai salah satu penyebab tersering diare pada anakanak. Penelitian ini menunjukkan bahwa pemberian probiotik pada keadaan infeksi dengan E.coli mampu menurunkan ekspresi TLR2, dan aktivasi NF-kB p50 yang berhubungan dengan penurunan reaksi inflamasi yang terjadi.

Dari analisa jalur, terdapat hubungan yang bermakna antara pemberian probiotik setelah pajanan dengan LPS

\section{DAFTAR PUSTAKA}

1. Suraatmaja S. Diare. Di dalam: Suraatmaja S (Ed). Kapita Selekta Gastroenterologi Anak. Jakarta: Sagung Seto; 2007.

2. Kresno SB. Imunologi: Diagnosis dan Prosedur Laboratorium. Edisi 5. Jakarta: Badan Penerbit Fakultas Kedokteran Universitas Indonesia; 2010.

3. Alexander C and Rietschel ET. Bacterial Lipopolysaccharides and Innate Immunity. Journal of Endotoxin Research. 2001; 7(3): 167-204.

4. Covert MW, Leung TH, Gaston JE, and Baltimore D. Achieving stability of Lipopolysaccharide-Induced NFkB activation. Science. 2005; 309(5742): 1854-1857.

5. Suparto P. Imunologi Intestinal. Di dalam: Suparto P pada penurunan aktivasi TLR2 (p:0,000, r:-0,806), dan peningkatan TLR4, namun dengan kekuatan hubungan yang kurang apabila dibandingkan dengan TLR $2(p=0,033$, $r=0,534)$. Hal ini menunjukkan bahwa pemberian probiotik setelah pajanan dengan LPS lebih mempengaruhi penurunan ekspresi TLR2 dibandingkan peningkatan TLR4. Sedangkan penurunan ekspresi tersebut lebih menurunkan aktivasi NF-kB p50 ( $p=0,006, r=0,656)$, dibandingkan peningkatan $p 65(p=0,026, r=-0,554)$.

Keterbatasan penelitian ini adalah tidak dilakukan pemeriksaan pada waktu yang berbeda, sehingga dapat dilihat apakah respon imun yang terjadi pada pemberian probiotik selama 7 hari disebabkan oleh pengaruh probiotik atau karena penurunan respon imun karena LPS.Selain itu karena penelitian ini dilakukan pada mencit, dengan didasarkan persamaan organ dan fungsi imunologis, namun perlu dikembangkan penelitian lebih lanjut terutama secara langsung kepada penderita.

Penelitian ini mmenunjukkan bahwa pemberian probiotik (L. rhamnossus dan L.acidophilus) meningkatkan respon imun dengan menunjukkan peningkatan ekspresi TLR2, TLR4 dan aktivasi NF-kB p50 dan p65 oleh sel mononuklear darah tepi dibandingkan kelompok kontrol. Sedangkan pemberian probiotik pada pajanan dengan LPS E.coli mampu menurunkan ekspresi TLR2, dan aktivasi NF-kB p50 pada sel mononuklear darah setelah pajanan dengan LPS E.coli. Selain itu, probiotik lebih mempergunakan jalur TLR2 yang kemudian akan menurunkan aktivasi NF-kB p50 apabila dibandingkan jalur melalui TLR4.

Berdasarkan keterbatasan penelitian ini, beberapa hal yang dapat dipertimbangkan untuk penelitian berikutnya antara lain perlu dilakukan penelitian yang membandingkan efek probiotik tersebut berdasarkan rentang waktu yang berbeda. Perlu dilakukan penelitian apakah peningkatan ekspresi TLR2, TLR4 dan aktivasi NFkB p50 dan p65 karena pemberian probiotik berhubungan dengan keadaan inflamasi atau tidak. Perlu dilakukan penelitian yang mampu melihat apakah sel mononuklear yang diperiksa apakah betul berasal dari proses homing dari saluran pencernaan. Selain itu, juga perlu dilakukan penelitian lebih lanjut dengan subjek manusia untuk mendapatkan bukti yang lebih kuat tentang respon yang terjadi karena pemberian probiotik pada keadaan infeksi oleh E.coli.

(Ed). Gangguan Sistem Imun Mukosa Intestinal. Surabaya: Graha Masyarakat IImiah Kedokteran Fakultas Kedokteran Universitas Airlangga; 2003.

6. Ljungh A and Wadstrom T. Lactic Acid Bacteria as Probiotic. Current Issues Intestinal Microbiol. 2006; 7(2): 73-90.

7. Isolauri E, Sutas $Y$, Kankaanpaa $P$, Arvilommi $H$, and Salminen S. Probiotics: Effects on Immunity. The American Journal Clinical Nutrition. 2001; 73(2): 444S550 S.

8. FAO/WHO. Health and Nutritional Properties of Probiotics in Food including Powder Milk with Live Lactic Acid Bacteria. Report of a joint FAO/WHO Expert Consultion on Evaluation of Health and Nutritional Properties of Probiotics in Food Including Powder Milk 
with Live Lactic Acid Bacteria. Cordoba, Argentina 2001; p. 1-32.

9. Floch $\mathrm{MH}$, Walker WA, Guandalini $\mathrm{S}$, et al. Recommendation for Probiotics Use-2008. Journal of Clinical Gastroenterology. 2008; 42: 104-108.

10. del Giudice MM and Brunese FP. Probiotics, Prebiotics, and Allergy in Children What's New in the Last Year? Journal of Clinical Gastroenterology. 2008; 42: 205-208.

11. Netea MG, Graaf C, Meer JW, and Kulberg BJ. Toll-Like Receptors and the Host Defense Against Microbial Pathogens. Journal of Leukocyte Biology. 2004; 75(5): 749-755.

12. Lee J-H, Lee B, Lee H-S, et al. Lactobacillus Suntoryeus Inhibits Pro-Inflammatory Cytokine Expression And TLR-4 Linked NF-Kb Activation In Experimental Colitis. International Journal of Colorectal Disease. 2009; 24(2): 231-237.

13. Lebeer S, Vanderleyden J, and Keersmaecker SCJD. Genes and Molecules of Lactobacilli Suporting Probiotic Action. Microbiology and Molecular Biology Review. 2008; 72(4): 728-764.

14. Lin PW, Myers LE, Ray L, et al. Lactobacillus Rhamnosus Block Inflammatory Signaling In Vivo Via Reactive Oxygen Species Generation. Free Radical Biology \& Medicine. 2009; 47(8):1205-1211.

15. Ishida-Fujii K, Sato R, Goto S, et al. Prevention of Pathogenic Escherichia coli Infection in Mice and stimulation of Macrophage Activation in Rats by an Oral Administration of Probiotic Lactobacillus casei I5. Bioscience Biotechnology Biochemistry. 2007; 7(4): 866-873.

16. Cosseau C, Devine DA, Dullaghan E, et al. The Commensal Streptococcus salivarius $K 12$ Downregulates the Innate Immune Responses of Human Epithelial Cells and Promotes Host-Microbe Homeostasis. Infection and Immunity. 2008; 76(9): 4163-4175.

17. Bai A, Ouyang Q, Xiao X, and Li SF. Probiotics Modulate Inflammatory Cytokine Secretion from Inflamed Mucosa in Ulcerative Colitis. International Journal of Clinical Practice. 2006; 60(3): 284-288.

18. Watanabe $\mathrm{T}$, Nishio $\mathrm{H}$, Tanigawa $\mathrm{T}$, et al. Probiotic Lactobacillus Casei Strain Shirota Prevents Indomethacin-Induced Small Intestinal Injury: Involvement of Lactic Acid. American Journal of Phsiology-Gastrointestinal and Liver Physiology. 2009; 297(3): 506-513.

19. Galdeano CM and Perdigon G. The Probiotic Bacterium Lactobacillus Casei Induces Activation of the Gut Mucosal Immune System Through Innate Immunity. Clinical and Vaccine Immunology. 2006; 13(2): 219-226.

20. Galdeano CM, LeBlanc AdMd, Vinderola G, Bonet MEB, and Perdigon G. Proposed Model: Mechanism of Immunomodulation Induced by Probiotic Bacteria. Clinical and Vaccine Immunology. 2007; 14(5): 485492.

21. Hajela N, Nair GB, and Ganguly NK. Are Probiotics a
Feasible Intervention for Prevention of Diarrhoea in the Developing World? Gut Pathogens. 2010; 2: 10-15.

22. Purswani MU, Eckert SJ, Arora HK, and Noel GJ. Effect of Ciprofloxacin on Lethal and Sublethal Challenge with Endotoxin and on Early Cytokine Responses in a Murine In Vivo Models. Journal of Antimicrobial Chemotherapy. 2002; 50(1): 51-58.

23. Miettinen M, Veckman V, Latvala S, Sareneva $T$, Matikainen S, and Julkunen I. Live Lactobacillus Rhamnosus and Streptococcus Pyogenes Differentially Regulated Toll-Like Receptor (TLR) Gene Expression in Human Primary Macrophage. Journal of Leukocyte Biology. 2008; 84(4): 1092-1100.

24. Lu YC, Yeh WC, and Ohashi PS. LPS/TLR4 Signal Transduction Pathway. Cytokine. 2008; 42(2): 145151.

25. Boele LC, Bajramovic JJ, Vries AMD, Voskamp-Visser IA, Kaman WE, and Kleij DVD. Activation of Toll Like Receptors and Dendritic Cells by a Broad Range of Bacterial Molecules. Cellular Immunology. 2009; 255(1-2): 17-25.

26. Bhattacharyya S, Dudeja PK, and Tobacman JK. Lipopolysaccharide Activates NF- B By TLR4-Bcl10Dependent And Independent Pathways In Colonic Epithelial Cells. American Journal of PhsiologyGastrointestinal and Liver Physiology. 2008; 295: 784790.

27. Gadjeva M, Tomczak MF, Zhang M, et al. A Role For NF(Kappa) B Subunits P50 And P65 in the Inhibition of Lipopolisaccharide-Induced Shock. The Journal of Immunology. 2004; 173(9): 5786-5793.

28. Karrasch T and Jobin C. NF-kB and the Intestine: Fried or Foe? Inflammatory Bowel Diseases. 2008; 14(1): 114-124.

29. Yan F and Polk DB. Disrubtion of NF-kB Signaling by Ancient Microbial Molecules: Novel Therapies of the Future? Gut. 2010; 59(4): 421-426.

30. Putera AM, Endaryanto A, Athiyyah AF, Ranuh IRG, dan Sudarmo SM. Pengaruh Pemberian Probiotik terhadap Kesigapan Respon Innate Mukosa dalam Menghadapi Pajanan Pathogen. [Penelitian]. Surabaya, Universitas Airlangga. 2009.

31. Petrof EO, Kojima K, Ropeleski MJ, et al. Probiotics Inhibits Nuclear Factor-Kb And Induced Heat Shock Proteins In Colonic Epithelial Cells Through Proteasome Inhibition. Gastroenterology. 2004; 127(5): 1474-1487.

32. Ruiz PA, Hoffmann M, Szcesny S, Blaut M, and Haller D. Innate Mechanism for Bifidobacterium Lactis to Activated Transient Pro-Inflammatory Host Responses in Intestinal Epithelial Cells after the Colonization of Germ-Free Rats. The Journal of Immunology. 2005; 115: 441-450.

33. Matsumoto S, Hara T, Hori T, et al. Probiotics Lactobacillus-Induced Improvement in Murine Chronic Inflammatory Bowel Disease is Associated with the Down-Regulation of Pro-Inflammatory Cytokines in Lamina Propia Mononuclear Cells. Clinical and Experimental Immunology. 2005; 140(3): 417-426. 
34. Kim JM, Kim JS, Kim YJ, et al. Conjugated Linoleic Acids Produced by Lactobacillus Dissociated IKK-G and Hsp90 Complex in Helicobacter Pylori-Infected Gastric Epithelial Cells. Laboratory Investigation. 2008; 88(5): 541-552.

35. Okada Y, Tsuzuki Y, Hokari R, et al. Anti-Inflammatory Effects of the Genus Bifidobacterium on Macrophages by Modification of Phospho-Ikb and SOCS Gene Expression. International Journal of Experimental Pathology. 2009; 90(2): 131-140.

36. Sougioultzis S, Simeonidis S, Bhaskar KR, et al. Saccharomyces Boulardii Produces a Soluble Antiinflammatory Factor that Inhibits NF-kB-mediated IL8 Gene Expression. Biochemical and Biophysical Research Communications. 2006; 343(1): 69-76.

37. Couper K, Blount D, and Riley EM. IL 10: The Master Regulatory of Immunity to Infection. The Journal of Immunology. 2008; 180(9): 5771-5777.

38. Asihing T. Pengaruh Pemberian L. rhamnosus dan
L.acidophilus terhadap Sekresi Sitokin Th1, Treg, Th17 pada Mukosa Usus Mencit yang Terpapar Lipolisakarida E.coli. [Penelitian]. Malang, Universitas Brawijaya. 2011.

39. Karin M, Cao Y, Greten FR, and Li ZW. NF-kB in Cancer: From Innocent by Stander to Major Culprit. Nature Reviews Cancer. 2002; 2(4): 301-310.

40. Conner JR, Smirnova II, Mosseman AP, and Poltorak A. IRAK1BP1 Inhibits Inflamation by Promoting Nuclear Translocation of NF-kB $p 50$. Proceedings of the National Academy of Science of the United States of America. 2010; 107(25): 11477-11482.

41. Lawrence T, Gilroy DW, Colville-Nash PR, and Willoughby DA. Possible New Role for NF-kB in the Resolution of Inflammation. Nature Medicine. 2001; 7(12): 1291-1297.

42. Larsson R, Rocksen D, Liliehook B, Jonsson A, and Bucht A. Dose-dependent Activation of Lymphocytes in Endotoxin-Induced Airway Inflammation. Infection and Immunity. 2000; 68(12): 6962-6969. 